\title{
The effect of temperature and chlorine residual on the presence of Legionella spp. in water systems of public and tourist facilities
}

\author{
Adna Bešić ${ }^{1}$ Zarema Obradovićc,3* , Adisa Dautbegović ${ }^{4}$ Amina Obradović ${ }^{2}$
}

'Public Health Institute of the FBiH, Sarajevo, Bosnia and Herzegovina, ${ }^{2}$ Public Health Institute of the Sarajevo Canton, Sarajevo, Bosnia and Herzegovina, ${ }^{3}$ Faculty of Health Studies, University of Sarajevo, Bosnia and Herzegovina, ${ }^{4}$ Euroinspekt Itd. Sarajevo, OJ Laboratory, Sarajevo, Bosnia and Herzegovina

\begin{abstract}
Introduction: Legionella bacteria are ubiquitous microorganisms mostly found in artificial water environments, especially those which produce aerosol, such as swimming pools, saunas, and spas. Development of Legionella depends on several factors, including water temperature and chlorine. The aim of this study was to evaluate the occurrence of Legionella spp. to the temperature and free residual chlorine in tap water, water from fountains, swimming pools, cooling and heating systems.

Methods: We collected 238 samples of water taken from different places and analyzed the presence of Legionella spp. by BAS EN ISO 11731-2:2009 - Water quality - Detection and enumeration of Legionella - Part 2: A direct membrane filtration method for waters with low bacterial counts, as samples were the waters with low expectancy of bacterial contamination compared to the temperature and free residual chlorine. The $\mathrm{X}^{2}$ test was used to show statistical significance.
\end{abstract}

Results: Legionella spp. was detected in $18.62 \%$ of tap water and in $8.82 \%$ samples of water taken from fountains, swimming pools, and cooling and heating systems. The highest number of positive samples were detected in waters with the temperature higher than $20^{\circ} \mathrm{C}$ and lower than $50^{\circ} \mathrm{C}$. The highest number of positive samples were reported by the concentration of free residual chlorine lower than $0.2 \mathrm{mg} / \mathrm{l}$. The $X^{2}$ test showed a statistically significant difference between positive and negative results for the presence of Legionella spp. among three groups of water samples.

Conclusion: The research has shown a connection between environmental factors and the presence of Legionella spp. in the water systems of public and tourist facilities.

Keywords: legionella, water temperature, free residual chlorine.

\footnotetext{
*Corresponding author: Adna Bešić,

Public Health Institute of the FBiH, Maršala Tita 9, Sarajevo,

Bosnia and Herzegovina, E-mail: a.besic@zzjzfbih.ba
}

Submitted: 12 January 2017/Accepted: 23 March 2017

DOI: https://doi.org/10.17532/jhsci.2017.413

\section{INTRODUCTION}

Legionella spp. are opportunistic pathogens which colonize water. They are mostly isolated from the artificial water environment, created by human action, such as the installation of hot water systems, showers, cooling towers, spas, fountains, humidifiers, and 
evaporation capacitors. These complex water systems potentially produce an aerosol that increases propagation and stimulates better distribution of bacteria in the area. Legionella bacteria in natural water systems (streams, rivers, lakes, and thermal springs) occur in relatively low numbers (1). The bacteria are isolated from various sources, even from the water found on the plants in rainforests and in subterranean waters, as well as in seas $(2,3)$. The optimal temperature for Legionella's growth ranges from 32 ${ }^{\circ} \mathrm{C}$ to $35^{\circ} \mathrm{C}$, although it survives in temperatures ranging from $0{ }^{\circ} \mathrm{C}$ to $68^{\circ} \mathrm{C}$ (4).

After being identified as a cause of pneumonia, Legionnaires's disease was referred to as legionellosis. These bacteria are classified under the genus Legionella, which belongs to the Legionellaceae family. To date, these have been recognised as the genus Legionella, Legionellaceae family, classified into 56 species and subspecies, with more than 70 kinds of serogroups. Others are still being discovered (5-9). Although more than 50 different species of Legionella have been described (4), not all are linked to community-acquired and nosocomial legionellosis in humans (9).

Legionella enters peoples' lungs through inhalation or aspiration. The transmission of the infection from human to human has not been determined yet. Legionella has a biphasic life cycle and it is contagious only if the bacterium is a short, thick stick with flagella, resistant to stress, sensitive to sodium, and without the ability to replicate (10).

The accumulation of bacteria on pipeline surfaces and biofilm formation are influenced by many factors. These include an inadequate flow rate or stagnation of the water, surface materials and roughness, the concentration and quality of nutrients and disinfectants, temperature, and the hydraulics of the system (11). Different distributions of Legionella species and serogroups have been observed depending on the water type. Significant amounts of Legionella spp. were detected in groundwater and potable water, whereas Legionella pneumophila was found to be adaptive to warm water systems, in which this organism multiplies most efficiently (12).

Water alone is insufficient to ensure the reproduction of Legionella (10). Bacteria of the genus Legionella normally inhabit freshwater or wet soil, but the major reservoirs are man-made aquatic environments, particularly warm water systems (13). In freshwater, Legionellae survive as intracellular parasites of free-living protozoans, which are their natural hosts $(14,15)$. The presence of biofilm is an important factor in the survival of Legionella bacteria and their development in water systems. The biofilm and its inner bacteria, including Legionella spp., formed within the protozoa, are more tolerant to chlorine and other antimicrobial agents at concentrations above those commonly used to disinfect water supply systems. These concentrations are shown to be lethal under the laboratory conditions for those organisms $(16,17)$. Tourism is a major industry in many European countries and is sensitive to health threats. In 1987, a European surveillance scheme for travel-associated Legionnaires' disease was introduced to detect cases (18) and control and prevent Legionella infections associated with tourism in both indigenous and foreign persons $(19,20)$. In recent years, several outbreaks of Legionnaires' disease have been recorded in the European Union (21,22). In July 2001, the world's largest epidemic of Legionnaires' disease was recorded in Spain (23).

There have been no recorded cases of the disease in Bosnia and Herzegovina, which is probably due to the lack of diagnostics. However, legionellosis has been repeatedly reported in foreign tourists who have stayed in our country during the incubation period of the disease. In such cases, it should be proceeded with the detection of pathogens and water sampling and analysis. Since 2011, the Federal Public Health Institute, Department of Environmental Health, has been in charge of Legionella detection. The aim of this study is to determine the relationship between environmental factors, temperature, and the concentration of free residual chlorine, as well as positive water samples. In addition, we aimed to determine the presence of Legionella spp. in water systems of public and tourist facilities in Bosnia and Herzegovina, and therefore, assess the epidemiological risk of legionellosis.

\section{METHODS}

\section{Sample collection}

A total of 238 samples were collected from tap water in the premises of catering facilities intended for accommodation, exterior and interior fountains, 
swimming pools and water contained in cooling and heating systems. The samples were taken across Bosnia and Herzegovina, during four seasons, in the period of three years. In the premises, the samples of hot water were collected from the water heating system (boilers), while the cold water samples were taken from the water supply system in the facilities. The water in cooling and heating systems was collected from the outlet tap from tanks. Hot water samples were collected from bathroom outlets (showerheads or bathroom taps), after water had flowed for 3-5 minutes to achieve continuous temperature. The water from cooling and heating systems, intended for heating or cooling of the selected objects, was collected from the outlet tap from tanks. The samples were stored in $1000 \mathrm{ml}$ sterile glass bottles and immediately transported to the laboratory for microbiological analyses, using portable coolers (at $4^{\circ} \mathrm{C}$ ). During sampling, we measured both the concentration of free residual chlorine and temperature. The temperature was measured by immersing the probe with a calibrated thermometer, manufacturer Tempo, until the stabilization of temperature values on the display was reached. The free residual chlorine was measured by the standard colorimetric technique - the $\mathrm{N}, \mathrm{N}$-diethyl-phenylenediamine method (HANNA Instruments 96701, Rhode Island, USA) at the time of sample collection. In order to neutralize free residual chlorine, sodium thiosulfate was added to the sterile bottles for bacteriological analysis $(20 \mathrm{mg} / \mathrm{l}$ according to BAS EN ISO 19458:2008).

While collecting the samples, close intention was paid to distribution of premises in relation to the dead pipes and possible water retention in these pipes and pipe joints. Water supply data and sample volume, water temperature as well as the presence and nature of the biocidal agent were recorded in the Work Order form. The form was submitted to the laboratory along with the sample to be available to the staff who conducted the analysis and interpreted the results. All steps to ensure quality assurance of the laboratory performance for microbiological analysis were applied and recorded.

\section{Microbiologic analysis}

The analysis of Legionella in water samples was carried out using the method BAS EN ISO
11731-2:2009 - Water quality - Detection and enumeration of Legionella - Part 2: Direct membrane filtration method for waters with low bacterial counts. The method describes the isolation and enumeration of organisms of the genus Legionella in water intended for human use (cold and hot tap water used for washing and personal hygiene), and the water for human consumption. The Legionella were also analyzed in treated recreational water (swimming pools and fountains), as well as in water from cooling and heating systems. Briefly, 1 litre of a water sample was concentrated by membrane filtration (cellulose membrane filters, manufactured by Sartorius, pore diameter $0.2 \mu \mathrm{m}$ ). The filter membrane was resuspended in $10 \mathrm{ml}$ of the original sample water, followed by cultivation on buffer charcoal yeast extract (BCYE) agar (Liofilchem, Italy). The plates were incubated at $36{ }^{\circ} \mathrm{C}$ in a humidified environment with $2.5 \% \mathrm{CO} 2$ for at least 10 days and examined in the beginning of day 5 with a dissecting microscope. The BCYE agar consisted of yeast extract $(10.0 \mathrm{~g} \times \mathrm{L}$-1), N-(2-Acetamido)2-aminoethanesulfonic acid (ACES) buffer $(5.0 \mathrm{~g}$ $\times \mathrm{L}-1)$, activated charcoal $(2.0 \mathrm{~g} \times \mathrm{L}-1)$ and agar $(15.0 \mathrm{~g} \times \mathrm{L}-1)$, further enriched with Legionella supplement solutions. The enrichment supplement solution contained essential growth factors, ferric pyrophosphate $(0.25 \mathrm{~g} \times \mathrm{L}-1)$, and cysteine hydrochloride $(0.4 \mathrm{~g} \times \mathrm{L}-1)$. The mixture for selective isolation contained vancomycin $(0.001 \mathrm{~g} \times \mathrm{L}-1)$ and colistin (45,000 IU), which prevent the growth of most of the flora associated with Legionella. Charcoal is the distinguishing element in the medium and has been described as a detoxifier, and the ACES buffer stabilizes the $\mathrm{pH}$ at 6.9, which is the optimal condition for growth. Colonies grown on BCYE agar were subsequently determined by the means of an agglutination test (Legionella latex test, Oxoid, Basingstoke, UK). The results were presented as colony-forming units per litre $(\mathrm{cfu} \times \mathrm{L}-1)$ on the basis of plate counts of Legionella colonies. The detection limit of the procedure was $25 \mathrm{cfu} \times \mathrm{L}-1$ (the mean of 2 plates).

\section{Statistical analysis}

The data obtained following the analysis of samples for the presence of Legionella, the recorded values of the temperature and free residual chlorine, were 
statistically analyzed by appropriate and verified methods, using a computer program Microsoft Excel 2010 and BioStat Pro version 5.8.3 ${ }^{\circledR}$ software.

A descriptive statistical processing, as well as a processing due to the statistical significance of differences in the obtained results were conducted by isolating and treating them as two separate groups. The results of the analysis of tap water samples or drinking water constituted the first group, including the water from hotel facilities and hostel and motel facilities. The results of water samples from fountains, swimming pools, and cooling and water heating systems formed the second group. The unpaired two-tiled $t$-test was used to compare the arithmetic means of water temperatures, as well as the means of residual chlorine concentrations in Legionella spp. positive and negative samples. The $\mathrm{X}^{2}$ test examined a statistically significant difference in the number of positive and negative samples for the presence of Legionella spp. between groups of samples. The sampling groups were formed depending on the measured values of the residual chlorine concentration and the temperature in the samples. Based on the measured sample temperature, the samples are classified into three groups. The first group consisted of samples at temperature of $20{ }^{\circ} \mathrm{C}$ or below, the second sample group at temperature above $20{ }^{\circ} \mathrm{C}$ and below $50{ }^{\circ} \mathrm{C}$, and the third sample group at temperature of $50^{\circ} \mathrm{C}$ and above.

\section{RESULTS}

Within the entire sample structure, the most common samples (184 samples, $77.31 \%$ ) belonged to the group of tap water collected from the hotel facilities. Furthermore, within the group of water taken from fountains, swimming pools and cooling and heating systems, the most common in the entire structure were the samples from external fountains (15 samples, $6.30 \%$ ).

\section{Results of testing water temperature effects on the presence of Legionella}

The average temperature of the water samples from fountains, swimming pools, and cooling and heating systems in which Legionella spp. was not detected was $25.06{ }^{\circ} \mathrm{C}$. In addition, the average temperature of the water samples in which the bacteria was found was $25.17^{\circ} \mathrm{C}$ (the lowest measured temperature was $9.1{ }^{\circ} \mathrm{C}$, while the highest was $48.3{ }^{\circ} \mathrm{C}$ ). According to the results of the $t$-test shown in Table 1 , there is no statistically significant difference in average temperatures within these two groups of samples.

In 98 samples of tap water, the measured temperature was $20{ }^{\circ} \mathrm{C}$ and below, while $14.28 \%$ of the samples was Legionella spp. positive. In 58 samples, the measured temperature was above $20{ }^{\circ} \mathrm{C}$ and below $50{ }^{\circ} \mathrm{C}$, whereas $34.48 \%$ of the samples tested positive for Legionella spp. The temperature of 50 ${ }^{\circ} \mathrm{C}$ and above was measured in 48 samples, out of which $8.33 \%$ tested positive for the presence of Legionella spp. (Table 2).

The $\mathrm{X}^{2}$ test confirmed a statistically significant difference between these three sample groups, including the samples in which Legionella spp. was detected, and those in which it was not detected. For the majority of positive samples of tap water, the measured temperature ranged from $20{ }^{\circ} \mathrm{C}$ to $50{ }^{\circ} \mathrm{C}$. The minimum number of positive samples was detected in the samples with the temperature at $50{ }^{\circ} \mathrm{C}$ and above (Table 2).

Among the water samples collected from fountains, swimming pools, and cooling and heating systems, 9 samples reached the temperature of $20^{\circ} \mathrm{C}$ and less. In these samples, Legionella spp. was not isolated. The temperature above $20^{\circ} \mathrm{C}$ and below $50{ }^{\circ} \mathrm{C}$ was measured in 25 samples, out of which $12 \%$ were reported positive for the presence of Legionella spp.

\section{The effect of the free residual chlorine on the presence of Legionella}

The average concentration of free residual chlorine in the samples of potable and non-potable water tested negative for Legionella spp. was $0.09 \mathrm{mg} / \mathrm{L}$. Moreover, the concentration of residual free chlorine in the samples which tested positive for these bacteria was $0.05 \mathrm{mg} / \mathrm{L}$. The Legionella spp. negative samples collected from fountains, swimming pools, and water from cooling and heating systems reported the concentration of free residual chlorine of $0.04 \mathrm{mg} / \mathrm{L}$, while zero free residual chlorine was detected in the Legionella spp. positive ones. According to the results of the $t$-test, there was no statistically significant difference in the average concentrations of residual chlorine in the samples 
TABLE 1. A comparative review of the value of basic statistical indicators and results of the $t$-test of the measured temperature

\begin{tabular}{lccccc}
\hline $\begin{array}{l}\text { Statistical parameter describing } \\
\text { water temperatures measured in }{ }^{\circ} \mathrm{C}\end{array}$ & \multicolumn{2}{c}{ Water samples from the rooms } & & \multicolumn{2}{c}{$\begin{array}{c}\text { Water samples from fountains, swimming } \\
\text { pools, and cooling and heating systems }\end{array}$} \\
\cline { 2 - 3 } & $\begin{array}{c}\text { Legionella spp. not } \\
\text { isolated }\end{array}$ & $\begin{array}{c}\text { Legionella spp. } \\
\text { Isolated }\end{array}$ & & $\begin{array}{c}\text { Legionella spp. not } \\
\text { isolated }\end{array}$ & $\begin{array}{c}\text { Legionella spp. } \\
\text { isolated }\end{array}$ \\
\hline Xav & 31.94 & 31.08 & & 25.06 & 25.17 \\
S & 16.05 & 12.01 & & 9.19 & 3.23 \\
sXav & 1.21 & 1.95 & & 1.65 & 1.87 \\
V & $50 \%$ & $39 \%$ & & $37 \%$ & $13 \%$ \\
t test & 0.31 & & & 0.019 & \\
p-value & 0.75 & & & 0.98 & \\
\hline
\end{tabular}

$\mathrm{AM}$ - mean, SD - standard deviation, SEM - standard error of the mean, CV - variation coefficient

TABLE 2. A compared review of the $X^{2}$ test results and differences in the number of positive and negative results against the measured temperature

\begin{tabular}{|c|c|c|c|c|c|c|c|c|}
\hline \multirow[t]{2}{*}{$\begin{array}{l}\text { Temperature } \\
\text { interval }\left({ }^{\circ} \mathrm{C}\right)\end{array}$} & \multicolumn{4}{|c|}{ Number of water samples from the rooms } & \multicolumn{4}{|c|}{$\begin{array}{l}\text { Number of water samples from fountains, swimming } \\
\text { pools, and cooling and heating systems }\end{array}$} \\
\hline & $\begin{array}{l}\text { Legionella spp. } \\
\text { not isolated }\end{array}$ & $\begin{array}{l}\text { Legionella } \\
\text { spp. isolated }\end{array}$ & Total & $\%$ (isolated) & $\begin{array}{l}\text { Legionella spp. } \\
\text { not isolated }\end{array}$ & $\begin{array}{l}\text { Legionella } \\
\text { spp. isolated }\end{array}$ & Total & $\%$ (isolated) \\
\hline $\mathrm{T} \leq 20$ & 84 & 14 & 98 & 14.28 & 9 & 0 & 9 & 0.00 \\
\hline $20<T<50$ & 38 & 20 & 58 & 34.48 & 22 & 3 & 25 & 12.00 \\
\hline$T \geq 50$ & 44 & 4 & 48 & 8.33 & 0 & 0 & 0 & 0 \\
\hline Total & 166 & 38 & 204 & 18.62 & 31 & 3 & 34 & 8.82 \\
\hline$X^{2}$ & 14.19 & & & & 1.18 & & & \\
\hline$p$-value & $0.0008^{*}$ & & & & 0.27 & & & \\
\hline
\end{tabular}

$\mathrm{X}^{2}-$ Chi square value, *statistically significant different

tested positive and negative for the presence of Legionella spp.

Out of the total number of the analyzed samples of tap water, 162 reported the concentration of free residual chlorine lower than $0.2 \mathrm{mg} / \mathrm{L}$, out of which $20.98 \%$ tested positive for the presence of Legionella spp. In the remaining 42 samples, the measured concentration of residual chlorine was higher than $0.2 \mathrm{mg} / \mathrm{L}$, and $9.52 \%$ of them tested positive for the presence of Legionella spp. The $\mathrm{X}^{2}$ test showed that there was no statistically significant difference in the number of positive and negative results between these two groups of samples. Among the analyzed samples of water from fountains, swimming pools, and water from cooling and heating systems, there was less than $0.2 \mathrm{mg} / \mathrm{L}$ concentration of free residual chlorine detected in 29 samples, out of which $3.37 \%$ were positive for Legionella spp. Only 2 samples reported the concentration of free residual chlorine exceeding the value of $0.2 \mathrm{mg} / \mathrm{L}$, and both samples tested negative for the presence of Legionella spp. The $\mathrm{X}^{2}$ test indicated no significant difference in the number of positive and negative results from these two groups of samples, categorized on the basis of free residual chlorine, as shown in Table 3.

\section{DISCUSSION}

Legionella bacteria usually live and reproduce in artificial aquatic environments. Recent studies have indicated the risk of presence of Legionella in systems with non-sterile water at temperature ranging from $25^{\circ} \mathrm{C}$ to $45^{\circ} \mathrm{C}$. Previous research have reported that the risk of Legionella maintenance exists in systems with non-sterile water at temperature ranging from $25^{\circ} \mathrm{C}$ to $45^{\circ} \mathrm{C}$. The optimum temperature for Legionella growth and development ranges from $32{ }^{\circ} \mathrm{C}$ to $42{ }^{\circ} \mathrm{C}$. Other factors that favor the development of Legionella are: stagnation of water, the presence of biofilms or nutrients, and the presence of other microorganisms. These are the risk factors that are examined within the building in the legionellosis risk assessment (24). We studied the 
TABLE 3. Comparison results of the $X^{2}$ test and the difference in the number of positive and negative results among samples with different concentrations of free residual chlorine

\begin{tabular}{|c|c|c|c|c|c|c|c|c|}
\hline \multirow[t]{2}{*}{$\mathrm{Cl}_{2}(\mathrm{mg} / \mathrm{L})$} & \multicolumn{4}{|c|}{ Number of water samples from the rooms } & \multicolumn{4}{|c|}{$\begin{array}{l}\text { Number of water samples from fountains, swimming } \\
\text { pools, and cooling and heating systems }\end{array}$} \\
\hline & $\begin{array}{l}\text { Legionella spp. } \\
\text { not isolated }\end{array}$ & $\begin{array}{l}\text { Legionella } \\
\text { spp. isolated }\end{array}$ & Total & $\%$ (isolated) & $\begin{array}{l}\text { Legionella spp. } \\
\text { not isolated }\end{array}$ & $\begin{array}{l}\text { Legionella } \\
\text { spp. isolated }\end{array}$ & Total & $\%$ (isolated) \\
\hline$<0.2$ & 128 & 34 & 162 & 20.98 & 29 & 3 & 32 & 3.37 \\
\hline$\geq 0.2$ & 38 & 4 & 42 & 9.52 & 2 & 0 & 2 & 0 \\
\hline Total & 166 & 38 & 204 & 18.62 & 31 & 3 & 34 & 8.82 \\
\hline$X^{2}$ & 2.89 & & & & 0.2 & & & \\
\hline$p$-value & 0.09 & & & & 0.65 & & & \\
\hline
\end{tabular}

$\mathrm{X}^{2}-$ Chi square value

water temperature as a factor which influences the Legionella development in water systems, including the tap water as well as the water not intended for consumption. In this study, the highest number of samples tested positive for Legionella spp. (34.48\%), during the analysis of water intended for drinking and bathing, was found in the group of samples with the water temperature above $20{ }^{\circ} \mathrm{C}$ and below $50{ }^{\circ} \mathrm{C}$. The smallest number of positive samples $(8.33 \%)$ was detected among the samples where the water temperature was $50{ }^{\circ} \mathrm{C}$ and above (Figure 1). In his research, Yu (25) reported the presence of Legionella in hot water tanks and thermal polluted rivers and stressed the importance of water temperature for Legionella colonization of water supply systems. During the research, in 62 out of 127 samples (48.82\%), temperature above $55^{\circ} \mathrm{C}$ was determined, while L. pneumophila was not detected in samples with temperature above this value (26). In our study, within the group with temperature below $20^{\circ} \mathrm{C}, 14$ of 98 samples $(14.78 \%)$ of tap water were tested positive for the presence of Legionella spp. Furthermore, in the group of water samples reaching temperature below $20{ }^{\circ} \mathrm{C}$ which were taken from hotels, 13 of the total number of 184 samples tested positive. In addition, in the group consisting of hotel water samples with temperature above $20^{\circ} \mathrm{C}$ and below $50{ }^{\circ} \mathrm{C}$, 19 samples were reported positive. Of the total number of samples (44), pertaining to the group with temperature above $50{ }^{\circ} \mathrm{C}, 3$ were tested positive on the presence of Legionella spp. Within the category of hostel and motel facilities, the largest number of positive samples was reported in the group with water temperature above $20^{\circ} \mathrm{C}$, but below $50{ }^{\circ} \mathrm{C}(28.57 \%)$. About

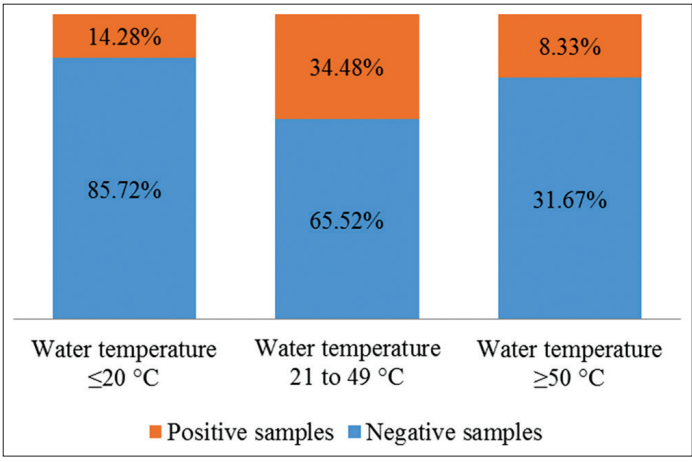

FIGURE 1. The percentage ratio of positive and negative samples for the presence of Legionella in water samples from taps with a different range of measured temperature.

$11.53 \%$ of the samples of water not intended for drinking, with temperature above $20{ }^{\circ} \mathrm{C}$ and below $50{ }^{\circ} \mathrm{C}$, tested positive on the presence of Legionella. The water temperature is known to be a decisive factor in Legionella colonization, since its growth is inhibited as the temperature exceeded $42{ }^{\circ} \mathrm{C}$; therefore, temperatures above $65^{\circ} \mathrm{C}$ have even been used in a disinfection study (27).

The water temperature of all the analyzed points, determined immediately after the collection, has reached low values, near $45^{\circ} \mathrm{C}$. This has enabled 1 Legionella multiplication, whereas, out of the 30 samples collected in the 3 analyzed hotels, 11 (36.7\%) were contaminated by Legionella spp. (28). The average measured temperature of tap water, covered in this survey, was $31.4^{\circ} \mathrm{C}$, with the minimum temperature of $26.8^{\circ} \mathrm{C}$ and the maximum of $48.8^{\circ} \mathrm{C}$. Rakic et al. (26) have proven the correlation between the temperature and the presence of 
L.pneumophila in water. The average temperature at which bacteria was present was $47.9{ }^{\circ} \mathrm{C}$ in regards to the middle temperature value of $53.8^{\circ} \mathrm{C}$ in the waters where Legionella was not detected. The average temperature of tap water samples negative to Legionella spp., which was intended for human consumption, was $31.94^{\circ} \mathrm{C}$. The samples of tap water tested positive for the presence of Legionella had the average temperature of $31.08^{\circ} \mathrm{C}$.

Research has shown that L.pneumophila was isolated both from chlorinated and non-chlorinated water samples. In the group of samples containing the concentration of chlorine lower than $0.2 \mathrm{mg} / \mathrm{L}$, $20.98 \%$ of samples tested positive. Moreover, the group of samples with the residual chlorine concentration higher than $0.2 \mathrm{mg} / \mathrm{L}$ reported $9.52 \%$ of positive samples (Figure 2). There is a statistically significant difference in the level of concentrations of residual chlorine taken from the samples of drinking water tested both positive and negative for the presence of Legionella spp. (Table 2). It has been proven that Legionella species can be present in water with free residual chlorine as well as in water where it was not found, confirming the Legionella species resilience to free residual chlorine (29). Rakic et al. (26) have reported that chlorine used for disinfecting water does not kill or slow down the growth and reproduction of L.pneumophila. The study showed that the concentration of free residual chlorine from 0.2 to $0.3 \mathrm{mg} / \mathrm{L}$ was found in water samples with the known presence of L.pneumophilom. Borella et al. (30) indicated that higher temperature and lower concentration of residual free chlorine stimulate the growth of L.pneumophila. Legionella species are more resistant to chlorine than other bacteria. The WHO drinking water quality guidelines recommend that the minimum target chlorine concentration at the point of delivery should be $0.2 \mathrm{mg} / \mathrm{L}$ in normal circumstances and $0.5 \mathrm{mg} / \mathrm{L}$ in high-risk circumstances (31). According to the research of Kuchta et al. (32), the concentration of chlorine of $2 \mathrm{mg} / \mathrm{L}$ reduces free Legionellae. The level of concentration was proven sufficient for maintaining a low number of colonies in hot water. This has also been confirmed by our results and a $20.98 \%$ percentage of positive samples in the group where the residual chlorine concentration was lower than $0.2 \mathrm{mg} / \mathrm{L}$.

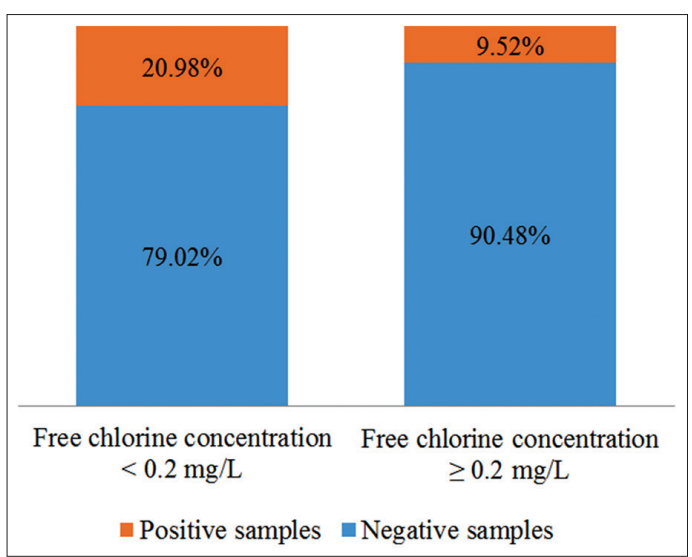

FIGURE 2. The comparison of positive and negative results with regards to the concentration of free residual chlorine.

Additionally, the percentage of positive samples, within the group where the residual chlorine concentration reached more than $0.2 \mathrm{mg} / \mathrm{L}$, was $9.52 \%$. The failure of disinfectants in controlling Legionella in drinking water systems has been attributed to the presence of protozoan hosts that act as a shield for pathogenic bacteria against disinfectants (33-36). However, legionellosis cases still occur in facilities with treated drinking water systems. Carvero et al. determined, under controlled laboratory conditions, how L. pneumophila resistance to common drinking water disinfection treatments was enhanced by its association with Acanthamoeba hosts. Inactivation models obtained showed that the increased resistance was significant for disinfectant exposures at the free chlorine concentrations lower than $0.5 \mathrm{mg}$ $\mathrm{L}^{-1}$ and at temperatures of $50^{\circ} \mathrm{C}$ and $55^{\circ} \mathrm{C}(37)$.

In 2002, the highest number of reported cases in tourists was associated with travelling in Italy (132 of 676 cases), where 35 clusters of travel-associated Legionnaires' disease were identified from July 2002 to October 2003. These mainly involved hotels and residences located in 14 Italian regions (Rota et al., 2007). In recent years, the presence of L. pneumophila has been reported in hot water samples in countries, such as Italy, France, Germany, Taiwan, and many others (38-41).

\section{CONCLUSION}

In this study, we examined the effects of temperature and concentration of free residual chlorine on 
the presence of the bacteria of the genus Legionella. The respective samples were taken from tap water as well as water samples from fountains, swimming pools, and water from cooling and heating systems. From a total of 204 analyzed samples of tap water, Legionella spp. was detected in $18.62 \%$. The majority of positive samples was detected when water temperatures ranged from $20{ }^{\circ} \mathrm{C}$ to $50{ }^{\circ} \mathrm{C}$. The lowest number of positive samples was reported once the water temperature reached $50{ }^{\circ} \mathrm{C}$ and above.

According to the results of the $\mathrm{X}^{2}$ test, the research on the impact of free residual chlorine on the presence of Legionella showed that there were no statistically significant differences in the number of positive and negative results. The absence of statistically significant differences was shown in regards to the concentration of free residual chlorine in tap water, as well as in the water samples from fountains, swimming pool, and water from cooling and heating systems.

\section{CONFLICT OF INTEREST}

The authors declare no conflict of interest.

\section{REFERENCES}

1. Barbot $\mathrm{V}$, Robert A, Rodier MH, Imbert C (2012): Update on infectious risks associated with dental unit waterlines. FEMS Immunol. Med. Microbiol., 65, 196- 204. https://doi.org/10.1111/j.1574-695X.2012.00971.x.

2. Riffard S, Douglass S, Brooks T (2001): Occurrence of Legionella in groundwater: An ecological study. Water Science and Technology, 43:99-102

3. Brooks T, Osicki RA, Springthorpe VS, Sattar SA, Filion L, Abrial D and Riffard S (2004): Detection and identification of Legionella species from groundwaters. Journal of Toxicology and Environmental Health, Part A, 67:1845-1859.

https://doi.org/10.1080/15287390490492449.

4. Diederen BM (2008): Legionella spp. and Legionnaires' disease. Journal of Infection; 56:1-12.

https://doi.org/10.1016/j.jinf.2007.09.010

5. La Scola B, Birtles RJ, Greub G, Harrison TJ, Ratcliff RM, Raoult D (2004): Legionella drancourtii sp. nov., a strictly intracellular amoebal pathogen. Int. J. Syst. Evol. Microbiol. 54, 699-703.

https://doi.org/10.1099/ijs.0.02455-0.

6. Park MY, Ko KS, Lee HK, Park MS, Kook YH (2003): Legionella busanensis sp. nov., isolated from cooling tower water in Korea. Int. J. Syst. Evol. Microbiol. 53, 77-80. https://doi.org/10.1099/ijs.0.02268-0.

7. Fields BS, Benson RF, Besser RE (2002): Legionella and Legionnaires' disease: 25 years of investigation. Clin. Microbiol. Rev. 15, 506-526. https://doi.org/10.1128/CMR.15.3.506-526.2002.
8. Bacterial Nomenclature Up-to-date.

http://www.dsmz.de/bactnom/bactname.htm (access: 2012.03.29).

9. Cooke, R. P. D. (2004). Hazards of water. Journal of Hospital Infection, Volume 57, Issue 4, 2004, Pages 290-293

http://dx.doi.org/10.1016/j.jhin.2004.05.004

10. Surman SB et al. (2002). Legionella pneumophila proliferation is not dependent on intracellular multiplication. In: Proceedings of the sixth international symposium on Legionnaires' disease, Ulm, Germany. Washington DC ASM Press, 86-89.

11. Hindre T, Bruggemann H, Buchrieser $C$, Hechard $Y(2008)$ : Transcriptional profiling of Legionella pneumophila biofilm cells and the influence of iron on biofilm formation. Microbiology 154, 30-41.

https://doi.org/10.1099/mic.0.2007/008698-0.

12. Emtiazi F, Shwartz T, Marten SM, Krolla-Sidenstein P and U (2004): Investigation of natural biofilms formed during the production of drinking water from surface water embankment filtration. Water Res. 38: 1197-1206. https://doi.org/10.1016/j.watres.2003.10.056.

13. Steinert MU, Hentschel and Hacker (2002): Legionella pneumophila: An aquatic microbe goes astray. FEMS Microbiol. Rev. 26:149-162.

https://doi.org/10.1111/j.1574-6976.2002.tb00607.x.

14. Borella P, Guerrieri E, I. Marchesi, Bondi M, and Messi P (2005): Water ecology of Legionella and protozoan: Environmental and public health perspectives. Biotechnol. Annu. Rev. 11:355-380.

https://doi.org/10.1016/S1387-2656(05)11011-4.

15. Harb OS, Gao LY and Abu Kwaik Y (2000): From protozoa to mammalian cells: A new paradigm in the life cycle of intracellular bacterial pathogens. Environ. Microbiol. 2:251-265.

https://doi.org/10.1046/j.1462-2920.2000.00112.x.

16. Martinelli $\mathrm{F}$ et al. (2000). A comparison of Legionella pneumophila occurrence in hot water tanks and instantaneous devices in domestic, nosocomial, and community environments. Current Microbiology, 41:374-376.

https://doi.org/10.1007/s002840010152.

17. Goossens $H$ (2001). Legionellosis: A new disease of Western hemisphere? Verhandelingen-Koninklijke Academie voor Geneeskdunde van Belgie, 63:359-377.

18. EWGLI (2002): European guidelines for control and prevention of trave associated Legionnaires' disease. Part 2. Definitions and procedures for reporting and responding to cases of travel associated Legionnaires' disease, p. 15-20. PHLS, London, United Kingdom.

19. Decludt B, Campese C, Lacoste M, Che D, Jarraud S and Etienne J (2004): Clusters of travel associated Legionnaires' disease in France, September 2001-August 2003. Eur. Surveill. 9:11-13.

20. Ricketts K and Joseph C (2004): Travel associated Legionnaires' disease in Europe: 2002. Eur. Surveill. 9:6-9.

21. Den Boer JW et al (2002): A large outbreak of legionnaires' disease at a flower show, the Netherlands, 1999. Emerg Infect Dis.; 8: 37-43. https://doi.org/10.3201/eid0801.010176.

22. Joseph CA (2002): New outbreak of legionnaires' disease in the United Kingdom. Editorial BMJ; 325:347-348.

https://doi.org/10.1136/bmj.325.7360.347.

23. Institut de veille sanitaire, Saint-Maurice, France. Outbreak of legionnaires' disease cases in northern France, November 2003 - January 2004: Update, 14 January. Eurosurveillance Weekly 2004; 8(3).

http://www.eurosurveillance.org/ew/2004/040115.asp

24. Obradović Z, Balta S, Mešić S, Pašagić S (2014): Legionellosis - risk assessment, Zbornik Radova: 26. Znanstveno - Stručno - Edukativn Seminar DDD i ZUPP 2014. Djelatnost dezinfekcije, dezinsekcije, deratizacije i zaštite uskladištenih poljoprivrednih proizvoda, Split, 25. do 28. ožujka 2014. pp. 189-197. 
25. Yu V (2000): Legionella pneumophila (Legionnaires' disease). In: Mandell GL, Bennett JE, Dolin R, eds. Principles and practice of infectious diseases, Philadelphia, Churchill Livingston, 2424-2435.

26. Rakic A, Peric J, Foglar L (2012): Influence of temperature, chlorine residual and heavy metals on the presence of Legionella pneumophila in hot water distribution systems. Ann. Agric. Environ. Med. 2012;19:431-436. [PubMed]

27. Mouchtouri V, Velonakis E, Hadjichristodoulou C (2012): Thermal disinfection of hotels, hospitals, and athletic venues hot water distribution systems contaminated by Legionella species, Am J Infect Control. 2007; 35: 623-627.

28. Lo Nostro A, Chechi E, Ducci B, Pesavento G (2011): Legionella contamination in hot water systems of hospitals, nursing homes, hotels, factories and spas in Tuscany-Italy, Public Health Department, University of Florence, Italy, Italian Journal of Public Health, Year 9, Volume 8, Number 1.

29. Bertram J, Chartier Y, Lee JV, Pond K, Whipple SL (2007): Legionella and the prevention of legionellosis. Geneva, Switzerland, WHO Press., World Health Organization, 2007. p. 30-37.

30. Borella $\mathrm{P}$ et al (2004): Legionella infection risk from domestic hot water. Emerging Infectious Diseases 10(3): 457-464.

https://doi.org/10.3201/eid1003.020707.

31. WHO. Guidelines for drinking-water quality. World Heal Organ. World Health Organization; 2008.

32. Kuchta JM, States SJ, McNamara AM, Wadowsky RM, Yee RV (1983): Susceptibility of Legionella pneumophila to chlorine in tap water, Appl Environ Microbiol. 1983 Nov; 46(5): 1134-1139.

33. Storey M V, Winiecka-Krusnell J, Ashbolt NJ, Stenström T-A. The efficacy of heat and chlorine treatment against thermotolerant Acanthamoebae and Legionellae. Scand J Infect Dis. 2004;36: 656-62. pmid:15370652.

34. Lin YE, Stout JE, Yu VL. (2011): Prevention of hospital-acquired legionellosis. Curr Opin Infect Dis.;24: 350-6. pmid:21666459. https://doi.org/10.1097/qco.0b013e3283486c6e.

35. Donlan RM et al (2005): Legionella pneumophila associated with the protozoan Hartmannella vermiformis in a model multi-species biofilm has reduced susceptibility to disinfectants. Biofouling;21: 1-7. pmid:16019386.

36. Thomas V, Bouchez T, Nicolas V, Robert S, Loret JF, Lévi Y(2004): Amoebae in domestic water systems: Resistance to disinfection treatments and implication in Legionella persistence. J Appl Microbiol. 2004;97: 95063. pmid:15479410.

https://doi.org/10.1111/j.1365-2672.2004.02391.x.

37. Carvero AS, Rodrigez MS, Puertas BA, Araujo MR (2015): Effect of Common Drinking Water Disinfectants, Chlorine and Heat, on Free Legionella and Amoebae-Associated Legionella, Plos one| doi:10.1371/journal. pone. 0134726 .

https://doi.org/10.1371/journal.pone.0134726.

38. Huang S W, Hsu B M, Wu S F, Fan C W, Shih F C, Lin Y C, Ji D D. Water quality parameters associated with prevalence of Legionella in hot spring facility water bodies. Water Res. 2010; 44: 4805-4811.

https://doi.org/10.1016/j.watres.2010.07.063.

39. Bargellini A, Marchesi I, Righi E, Ferrari A, Cencetti S, Borella P, Rovesti S. (2011): Parameters predictive of Legionella contamination in hot water systems: Association with trace elements and heterotrophic plate counts. Water Res.; 45: 2315-2321. https://doi.org/10.1016/j.watres.2011.01.009.

40. Buse HY, Schoen ME, Ashbolt NJ (2012): Legionellae in engineered systems and use of quantitative microbial risk assessment to predict exposure. Water Res.; 46: 921-933.

https://doi.org/10.1016/j.watres.2011.12.022.

41. Ditommaso S, Giacomuzzi M, Gentile M, Ruggenini Moiraghi A, Zotti C M. Effective environmental sampling strategies formonitoring Legionella spp contamination in hot water systems. Am J Infect Control. 2010; 35: 344-349. https://doi.org/10.1016/j.ajic.2009.09.016. 